\title{
State and dynamics of commercial fish stock recruitment in the Dnieper-Bug mouth system
}

\author{
Buzevich I. ${ }^{1}$, Geina K. ${ }^{2}$ \\ Institute of Fisheries NAAS, Obukhivska Str.,135, Kyiv, 03164, Ukraine; e-mail: ' busevitch@ukr.net
}

The purpose. To determine quantitative and quality indicators of groups of young fishes as a basis for formation of source of raw materials of trade and biological diversification of Dnieper-Bug mouth system. Methods. Field ichthyologic probes, mathematical calculations. Results. Data on species composition, numerosity and allocation of groups of young fishes of Dnieper-Bug mouth system are taken and analysed. Basic trends in dynamics of catches of young fishes on force of control fishing gears, as integral characteristics of natural reproduction and basis for enforcement of source of raw materials of trade are specified. Conditions of reproduction of different ecological groups of fishes are probed. Dynamics of quality contents of commercial catches is analysed. Conclusions. Basis for commercial catches of fishes of Dnieper-Bug mouth system made Black-sea sprat $(62,2 \%)$ and Prussian carp $(21,4 \%)$. Part of a class «valuable trade sorts» made $7,3 \%$ of overall catch. Self-reconstituting populations of fishes ensured formation of $93,5 \%$ of a catch, i.e. natural reproduction remained the basic source of enforcement of source of raw materials of piscatory trade of Dnieper-Bug mouth system. According to probes of 2006-2015 period young fishes of 18 sorts were fixed on foreshore plots, the basis of numerosity $(56,3-57,2 \%)$ made invaluable and minor in economic ratio sorts Prussian carp, Black-sea sprat, atherina. Among valuable trade sorts the most numerous were roach $(7,3 \%)$ and bream (3,4\%). These species formed $16.4 \%$ of total catch in gill nets in $2010-2017$. Interannual dynamics of numerosity of young fishes of trade sorts for the last 10 years specifies that at maintenance of optimum hydrological regime of Dnieper-Bug mouth system it is possible to forecast stability of commercial catches in immediate prospects.

Key words: fish fauna, species composition, young fishes, natural reproduction, source of raw materials of trade.

$$
\text { https://doi.org/10.31073/agrovisnyk201901-06 }
$$

INTRODUCTION. Most noticeable changes in composition ichthyofauna lower reaches of Dnepr took a place in the first ten years after building of Kakhovskoy GES. Exactly in this period there was becoming of ichthyofauna of the Dnieper-Bug mouth system in the new terms of regulated flow with forming on principle new ichthyocomplex of fluviolacustrine type [1-2].

In composition finfishess the Dnieper-Bug mouth system to regulated of flow of Dnepr 79 species which belonged to 18 families were registered [3]. More late researches which were carried out in a period to to and after regulated of flow of Dnepr Kakhovskoy GES rotined that high-quality description of catches suffered on a background the general decline of volumes of industrial exception of fish, substantial changes [4]. Thus to the analysis of industrial catches and these catches by the instruments of fingerling at the end of 80th beginning of 90th of the last century 75 types of finfishess, which belong to 23 families from which in lower reaches of Dnepr, are registered in the Dnieper-Bug mouth system - 54, lower reaches South Bug 55, Dniepr and Bug estuaries -67 species [5]. General quantity of species at a ichthyofauna pool Dnepr for today is estimated in 85 species, to the pool South Bug is 70 species [6]. Thus 26 species fall into a category "have an economic value" [7-8].

Purpose of researches: establishment of quantitative and high-quality indexes of groupments of young people of finfishess, as bases of forming of source of raw materials of trade and biological variety of the Dnieper-Bug mouth system.

Material and methods of researches. Collection of ichthyological materials on the biological state of groupments of young people of basic industrial types of finfishess of the Dnieper-Bug mouth system, as 
quantitative description of addition to the industrial herd [9], was conducted on stationary observant points. Efficiency of spawning of representatives of іхтіофрауни of experimental reservoir was set on the basis of analysis of ichthyological tests which was taken away in a summer-autumn period 2006-2015 from the catches of instruments of fingerling of catch - fingerling "тканка", волокуша of fingerling, trawl of fingerling [10-11]. By researches all of aquatorium of experimental reservoir was overcame on the proper network of the stations and cuts. All was analysed catches on 375 stations; the general area of облову made more than $50000 \mathrm{~m}^{2}$ off-shore plots. For description of industrial catches official statistical information was utillized.

Results of researches. The dynamics of industrial catches of water biotresources in the DnieperBug mouth system has a general tendency to the decline: from 3,1-4,0 thousand tons in 2005-2010 to 2,23,0 thousand tons in 2011-2015 and 2,0-2,5 thousand tons in 2016-17 By basic species which stipulated the decline of catches in the last years were black-sea sprat $(65,7 \%)$ and bighead carp $(32,3 \%)$. The fishing-out of cell-nets finfishess of aborigines in the last years purchased a tendency to growth, mainly due to the prussian carp on the particle of which dropped $62,5 \%$ general increase of catches; the reliable increase of fishing-out is marked for a bream (12,4\% general increase) and roach (10,2 \%).

In the period of 2013-2017 22 types of finfishess were fixed industrial statistics, basis of catches in this period was folded by black-sea sprat $(62,2 \%)$ and prussian carp $(21,4 \%)$; on the particle of category "valuable commercial species" was 7,3\% general fishing-out.

The particle of species of aborigines (autochtonic) in the general supply of іхтіорауни of industrial areas of the Dnieper-Bug mouth system by the state on 2017 made, without the account of bleak and blacksea sprat, 39,0\% (the level of industrial death rate is here accepted at the level of $25 \%$ [12]); basis of industrial supply was made by an adentitious object - prussian carp. Total particle of species with an exceptionally natural recreation in commercial catches on the average was $93,5 \%$; the maximal specific fishing-out of introductory (9,9\%) was fixed in 2013

From data of researches 2011-2015, in the groupments of young people of finfishess on off-shore biotops of the Dnieper-Bug mouth system such species are not fixed: garfish, whiting, goatfish which can be the relative certificates of certain desalination of estuary. However much the dynamics of river flow of Dnieper in 2014-2015 specifies on reverse. Thus increase of amount of marine species which are registered in the Dnieper-Bug mouth system not observed, that in same queue can specify on their low quantity in adjoining to the estuary part of the Black sea.

At the same time substantial growth of quantity of black sea anchovy is marked and so-iuy mullet, which are widespread in the Bug estuary and the last years constantly registered on the adjoining to the estuary aquatoriums of lower reaches South Bug.

From the freshwater group of finfishess, knife-fish and blue bream left off to be registered, which yet in the last century met single copies.

Thus the personal touch of contemporaneity is diminishing of general amount of species, however much similar changes touched the representatives of marine іхтіофрауни in a greater degree, which called at the estuarine system at the increase of salinity of the Dnepr and Bug estuaries.

Results of registration works from determination of relative quantity an underyearling is specified on that in the Dnieper-Bug mouth system of spawning on the average near 24 types of finfishess, from what 18 behave to industrial. Majority is presented phytophilous ichthyofauna, where main positions occupy the inhabited forms. In the period of 2006-2010 marked a tendency became to the decline of general quantity underyearling in lower reaches of Dnieper (table. 1). 
Table $1 \mathrm{~A}$ relative quantity is an underyearling of commercial cath species of finfishess in lower reaches of Dnieper, 2006-2010, ind./effort

\begin{tabular}{|l|c|c|c|c|c|}
\hline \multirow{2}{*}{ Species } & \multicolumn{5}{c|}{ Years } \\
\cline { 2 - 6 } & 2006 & 2007 & 2008 & 2009 & 2010 \\
\hline Roach & 27,3 & 12,7 & 19,2 & 10,4 & 9,8 \\
\hline Bream & 13,1 & 5,8 & 7,0 & 4,6 & 5,1 \\
\hline Pike perch & + & + & 0,1 & 0,1 & 0,2 \\
\hline Vimba & + & + & 0,1 & 0,1 & 0,2 \\
\hline Prussian carp & 54,5 & 51,6 & 46,4 & 47,8 & 44,2 \\
\hline Silver bream & 29,7 & 26,3 & 25,6 & 19,6 & 15,3 \\
\hline Rudd & 22,5 & 21,4 & 19,8 & 14,2 & 13,9 \\
\hline Perch & 3,7 & 3,3 & 2,9 & 1,7 & 2,1 \\
\hline Common carp & + & + & 0,3 & 0,2 & 0,3 \\
\hline Chub & - & - & - & + & + \\
\hline Pike & 6,1 & 5,4 & 5,6 & 4,8 & 5,5 \\
\hline Black-sea shad & + & + & 0,5 & 0,7 & 2,6 \\
\hline Black-sea sprat & 47,6 & 42,7 & 48,6 & 36,5 & 31,4 \\
\hline Bleak & 11,2 & 10,8 & 9,5 & 8,4 & 9,2 \\
\hline Atherina & 31,6 & 30,5 & 32,8 & 29,6 & 31,3 \\
\hline Gobies & 7,2 & 5,3 & 6,7 & 5,8 & 6,1 \\
\hline
\end{tabular}

The basic particle of relative quantity of underyearlings of semiclock-house of ichthyofauna is formed by a roach and bream. Dominantom usually a roach comes forward here. However during 2006-2010 the substantial decline of relative quantity is marked underyearling to 9,8 ind./effort, that is investigation of general tendency of reduction of stocks of semiclock-house of іхтіофрауни. A similar situation in a considered period was characteristic after a bream, when to 2010 quantity underyearling in lower reaches of Dnepr substantially went down and evened 5,1 ind./effort.

At this time the indexes of the "productivity» on a pike perch and рибцю had an insignificant, but permanent tendency to the increase. At the beginning of the considered period these species in the instruments of fingerling were registered as «single copies». However during 2008-2010 relative quantity underyearling grew and made 0,1-0,2 ind./effort. For a pike perch such situation can be the certificates of fade of places of recreation and working out. Usually a pike perch is reproduced on spawning-grounds which are located in an estuary and pre-estuarine areas of lower reaches of Dnepr. Here takes a place and working out of him junior age-dependent groups. As a result of unfavorable hydrological terms which are related to the low charges of water in a summer period and, as a result by appearance of the areas saturated the sulphuretted hydrogen, the underyearlings of pike perch migrate to the reservoirs of lower reaches of Dnepr.

Places of recreation of рибця, оpposite, always were in the river system of lower reaches of Dnepr. Efficiency of recreation of this kind was in complete dependence on reclamative measures which headed for creation of artificial spawning-grounds - «vimba's dikes». As a result of diminishing of volumes of 
reclamative works, and then and in general their stopping, the quantity of herd of vimba went down considerably, and during the protracted period the underyearlings of vimba were not registered in general.

After proceeding in works from formation of artificial spawning-grounds during 2006-2010 there is a tendency to gradual renewal of quantity of his herd which supported the proper reproductive ability of herd with the «productivity» to 0,3 ind./effort. in 2014

An important moment $2006-2010$ is proceeding in the quantity of clock-houses of herring, in particular black-sea shad. At the beginning of the considered period in lower reaches of Dnieper underyearlings were registered поодиноким copies. However from 2008 to on 2010 substantial growth of relative quantity (almost in 5 times) is marked - from 0,5 to 2,6 ind./effort. The insignificant decline of quantity of тюльки (to 31,4 ind./effort.), which can definitely conform to growth of quantity of junior agedependent groups of pike perch was marked at this time.

The personal touch 2011-2015 was gradual increase of general quantity underyearling in lower reaches of Dnepr; in particular the positive of the noted sentinel interval is a tendency became to growth of quantity of communicating herring - пузанка from 3,3 ind./effort. to 14,7 ind./effort. (table. 2).

Table 2 A relative quantity is an underyearling of commercial cath species of finfishess in lower reaches of Dnieper, 2011-2015, ind./effort

\begin{tabular}{|l|c|c|c|c|c|}
\hline \multirow{2}{*}{ Types of finfishess } & \multicolumn{5}{|c|}{ Years } \\
\cline { 2 - 6 } & 2011 & 2012 & 2013 & 2014 & 2015 \\
\hline Roach & 14,1 & 15,2 & 21,3 & 19,6 & 15,1 \\
\hline Bream & 6,8 & 4,8 & 9,5 & 10,1 & 9,3 \\
\hline Pike perch & 0,7 & 0,3 & 0,8 & 1,9 & 1,6 \\
\hline Vimba & 0,2 & 0,3 & 0,3 & 0,3 & 0,1 \\
\hline Prussian carp & 48,7 & 51,4 & 59,8 & 63,7 & 74,3 \\
\hline Silver bream & 15,7 & 16,8 & 17,7 & 16,4 & 16,2 \\
\hline Rudd & 14,8 & 13,6 & 19,6 & 18,1 & 17,9 \\
\hline Perch & 1,9 & 4,2 & 7,9 & 8,2 & 8 \\
\hline Common carp & 0,6 & 0,9 & 1,5 & 1,9 & 2,3 \\
\hline Chub & - & + & + & - & - \\
\hline Pike & 6,4 & 6,9 & 11,6 & 10,4 & 9,6 \\
\hline Black-sea shad & 3,3 & 9,2 & 13,4 & 16,5 & 14,7 \\
\hline Black-sea sprat & 30,1 & 29,4 & 33,8 & 36,5 & 49,1 \\
\hline Bleak & 8,6 & 8,6 & 10,5 & 9,3 & 8,1 \\
\hline Atherina & 28,5 & 37,5 & 41,3 & 39,8 & 42,5 \\
\hline Gobies & 6,9 & 6,3 & 6,9 & 6,7 & 5,9 \\
\hline
\end{tabular}

Among other representatives of semiclock-house of ichthyofauna it follows notices gradual growth of quantity underyearling of pike perch from 0,8 to $1,6-1,9$ ind./effort. Thus the productivity after a roach and bream was stabilized at the level of 14,1-21,3 ind./effort. but 4,8-10,1 ind./effort. accordingly.

Supervisions specify the underyearling of twoddle species on growth of relative quantity, where the silvery European carp has a dominant value, when the «productivity» during the last five years was 
increased from 48,7 to 74,3 ind./effort. Thus such indexes after rudd and silver bream were relatively stable and changed scope from 13,6 to 19,6 ind./effort., and in relation to predators (pike, perch) the increase of relative quantity is marked during $2011-2015$ accordingly in 1,5 and 4,2 times.

In a general amount underyearling specific gravity that water species finds out a certain tendency to the increase from $62,35 \%$ in 2001-2005 to $71,98-75,45 \%$ in 2006-2015 It resulted in the decline of particle of semicommunicating species - roach, bream, рибця and pike perch from $30,6 \%$ to $7,5 \%$. However it should be noted that indexes of fishing-out of young people of these species during the last years characterized certain stability: the average annual quantity of roach in 2006-2010 made 15,9 ind., in 2011-2015 are 17,1 ind., bream according to 7,1 and 8,1 ind..

The basic particle of underyearlings of twoddle species was formed by the prussian carp $(21,3-$ $21,6 \%)$ and amur bitterling (30,6-34,8\%). Growth of particle of atherina (from 8,1 to $15,0 \%$ ) is thus marked, and bleak which is more valuable object of feed of pike perch and perch, vice versa went down from 4,3 to a $3,6 \%$ general amount underyearling of twoddle species. Also during the last years a quantity was increased, and accordingly and particle, carp which is investigation of natural recreation from infused with generations in previous years. Thus substantially the «productivity» grew after foreign species - psevorasbora (to 11,7 ind./effort.) and by a sun perch - to 5,1 ind./effort.

For communicating species was characteristic growth of quantity of black-sea shad - from 2,4 ind./effort in 2011 to 8,1 ind./effort in 2015 Registered a sturgeon single copies, and in a specific relation were presented the russian sturgeon and stellate sturgeon.

If to examine the structure of groupments of young people of finfishess after fisheries categories, its basis is stably $(57,2 \%$ in $2006-2010$ and $56,3 \%$ in $2011-2015)$ made by of little value in an economic relation species (ulack-sea sprat and atherina) and second-rate from the point of view a commodity value a cell-nets species is the prussian carp. However general stake of species which fall into a category industrially valuable, in the last 10 years remains at high enough level $-22,6-24,7 \%$, mainly due to a roach and bream.

Consequently the personal touches of modern high-quality structure of ichthyofauna of the Dnepr and Bug estuaries is a decline of specific quantity of semicommunicating species at the proper increase of particle of twoddle species, mainly naturalizing introductories.

\section{Conclusion}

Last years, the majority of commercial catches in the Dnieper-Bug mouth system consists of Blacksea sprat $(62.2 \%)$ and Prussian carp $(21.4 \%)$; the category of "valuable commercial species" composed $7.3 \%$ of the total catch. Self-reproductive fish populations ensured formation of $93.5 \%$ of the total catch. i.e. natural reproduction remains the major source of the recruitment of commercial fish stocks in the DnieperBug mouth system. According to the data of studies of 2006-2015, juveniles of 18 fish species were recorded in the littoral zone, the majority of which (56.3-57.2\%) were low value and secondary species - Prussian carp, Black-sea sprat, atherina. Among valuable commercial species, the most abundant were roach (7.3\%) and bream (3.4\%); at the same time, these species formed $16.4 \%$ of the total catch in gill nets in 2010-2017. The inter-annual dynamics of the abundance of juveniles of commercial fish species during last 10 years has been characterized by positive trends that under condition of the maintenance of optimum hydrological regime of the Dnieper-Bug mouth system indicates in the possibility of ensuring stable commercial catches in the nearest future.

\section{Bibliography}

1. Verlatyi D.B., Mezhzheryn S.V., Fedorenko L.V. (2009) Vydovoi sostav y chyslennost prokhodnykh y presnovodnykh ryb Nyzhnedneprovskoi estuarnoi systemy: dynamyka $v$ XX st. $v$ sravnenyy s Nyzhnym Dunaem // Vtstnik zoologii. - 43(3). - S.231-244 [in Russian].

2. Sherman I.M., Heina K.M., Kutishchev S.V., Kutishchev P.S. (2013) Ekolohichni transformatsii richkovykh hidroekosystem ta aktualni problemy rybnoho hospodarstva// Rybohospodarska nauka Ukrainy. №4 (26). - S. 5-16. [in Ukrainian] 
3. Ambroz A.Y. (1956) Ryby Dnepra, Yuzhnoho Buha i Dneprovsko-Buhskoho lymana. -K.: Yzd-vo AN USSR. - 405 s. [in Russian].

4. Zalumy S.H. Yzmenenyia v rybnom promysle v nyzoviakh Dnepra, Yuzhnoho Buha i DneprovskoBuhskoho lymana posle zarehulyrovanyia // Rybnoe khoziaistvo. - K.: Urozhai, 1973. - Vyp. 17. - S. 81-8 [in Russian]

5. Pravotorov B.Y., Sarkysian V.Y., Horbonos V.N., Heina K.N. (2005) Ulovy i sovremennoe sostoianye promyslovykh ryb Dneprovsko-Buhskoi ustevoi oblasty.// Rybnoe khoziaistvo Ukrainy. 5(40). - S. 15-18. [in Russian]

6. Movchan Yu.V. (2005) Do kharakterystyky riznomanittia ikhtiofauny prisnovodnykh vodoim Ukrainy (taksonomichnyi sklad, rozpodil po richkovym baseinam, suchasnyi stan)//Zbirnyk prats Zoolohichnoho muzeiu, №37.- S. 70-82 [in Ukrainian].

7. Vorobjeva V.A., Pravotorov B.Y., Chekulaeva M.S. (2002) Promyslovye ryby nyzhneho Dnepra, Dneprovsko-Buhskoho lymana, Kakhovskoho vodokhranylyshcha, Chornoho y Azovskoho morei. Kherson: Temp/ - 34 s [in Russian]

8. Movchan Yu.V. (2011) Ryby Ukrainy - K.: NPPM. - 420 s [in Ukrainian]

9. Kotovska H.O., Ozinkovska S.P., Khrystenko D.S., Poltoratska V.I. (2009) Vykorystannia danykh vidnosnoi chyselnosti molodi ryb Kremenchutskoho vodoskhovyshcha dlia prohnozuvannia promyslovoho vylovu // Rybne hospodarstvo. K.: Ahrarna nauka, Vyp. 66. S. 77-80 [in Ukrainian].

10. Metodyka zboru i obrobky ikhtiolohichnykh i hidrobiolohichnykh materialiv z metoiu vyznachennia limitiv promyslovoho vyluchennia ryb z velykykh vodoskhovyshch i lymaniv Ukrainy (1998). - Kyiv: IRH UAAN/ - 47 s [in Ukrainian].

11. Metody hidroekolohichnykh doslidzhen poverkhnevykh vod (2006) / O.M. Arsan, O.A. Davydov, T.A. Diachenko ta in.]. - K.: Lohos. -408 s. [in Ukrainian]

12. Chuklin A.V. (2012) Pryntsypy vstanovlennia dopustymykh obsiahiv vylovu vodnykh bioresursiv u dniprovskykh vodoskhovyshchakh//Rybohospodarska nauka Ukrainy. - Vyp. 3.- S. 3-8 [in Ukrainian]. 